\title{
Coping pada Remaja yang Kecanduan Bermain Game Online
}

\author{
Ganda Yogi Wiguna dan Yohanes Kartika Herdiyanto \\ Program Studi Psikologi, Fakultas Kedokteran Universitas Udayana \\ herdiyanto@unud.ac.id
}

\begin{abstract}
Abstrak
Masa remaja merupakan masa transisi dari anak-anak menuju dewasa yang di dalamnya terjadi perubahan fisik dan perubahan psikologis. Pada masa remaja mulai muncul rasa ingin tahu yang besar yang menyebabkan remaja tersebut mencoba hal-hal yang baru, dan mengikuti trend yang booming di teman sebayanya, salah satu trend tersebut adalah game online. Game online merupakan game yang berbasis elektronik visual serta menggunakan jaringan internet. Sebagai salah satu trend yang ramai dimainkan, game online memiliki dampak positif dan negatif. Dari dampak negatif game online akan menimbulkan masalah-masalah pada remaja yang kecanduan bermain game. Masalah-masalah ini mendorong remaja untuk melakukan beberapa coping atau solusi untuk menyelesaikannya. Masalah dan coping inilah yang akan diteliti oleh peneliti. Tujuan dari penelitian ini adalah untuk mengetahui masalah apa saja yang dialami remaja yang kecanduan bermain game online dan coping yang dilakukannya untuk mengatasi masalah tersebut. Penelitian ini menggunakan metode penelitian kualitatif dengan pendekatan fenomenologi. Penelitian ini menggunakan lima responden yang dapat digolongkan menjadi belum bekerja, sudah bekerja dan yang ketiga masih kuliah. Hasil dari penelitian ini adalah masalah yang dialami oleh remaja yang kecanduan bermain game dapat dikelompokkan menjadi empat pokok masalah yaitu masalah dengan diri sendiri, masalah dengan orangtua, masalah dengan pacar, dan masalah dengan teman. Berikutnya coping yang dilakukan remaja yang menjadi gamers tersebut dapat dibagi menjadi dua yaitu yang efektif dan yang tidak efektif.
\end{abstract}

Kata kunci: remaja, kecanduan, game online, masalah, coping

\begin{abstract}
Adolescence is a period of transitions of children toward adulthood which changes the physical and psychological changes. On adolescence began to appear a great curiosity which led the teenagers try things that are new, and trend following the boom in peers, one trend is online gaming. The online game is a game based electronic visual as well as use the internet network. As one of the vibrant trend played out, online gaming has positive and negative impacts. From the negative effects of online gaming will cause problems in teenagers who are addicted to the game play. These problems are encouraging teens to do some coping or solutions to solve them. Problems and coping with this will be examined by the researchers. The purpose of this research is to find out what problems experienced by teenagers who are addicted to playing games online and coping with is doing to fix the issue. This research uses qualitative research methods with the phenomenology of approach. The study uses five respondents can be classified into haven't worked, it worked and the third was in college. The results of this research are the problems experienced by teenagers who are addicted to playing games can be grouped into four subject matter that is the problem with yourself, problems with parents, problems with a boyfriend, and problems with friends. Subsequent coping done teenagers who become gamers can be divided into two effective and ineffective.
\end{abstract}

Keywords: adolescence, online games, problems, coping 


\section{LATAR BELAKANG}

Masa remaja merupakan salah satu tahap perkembangan sepanjang rentang kehidupan manusia yang paling unik, penuh dinamika, sekaligus penuh dengan tantangan dan harapan (Steinberg, 1993). Pada masa remaja terjadi perubahan mendasar yang sangat berpengaruh terhadap eksistensi dan perannya dalam berbagai dimensi kehidupan. Perubahanperubahan itu antara lain meliputi jasmani, rohani, pikiran, perasaan, dan sosial yang dapat menunjukkan sikap dan perilaku berbeda dari masa sebelumnya yaitu masa kanakkanak. Pada masa ini remaja sudah ingin melepaskan semua identitas serta atribut-atribut kanak-kanaknya. Hal tersebut menjadikan masa remaja menjadi masa transisional antara masa kanak-kanak dengan masa dewasa.

Pada masa ini remaja sangat mudah dipengaruhi oleh teman sebayanya. Santrock (2003) menyebutkan tekanan untuk mengikuti teman sebaya menjadi sangat kuat di masa remaja. Pada masa ini remaja akan lebih mendengarkan perkataan serta nasihat dari teman-temannya daripada mendengarkan perkataan dan nasihat dari orangtuanya sendiri. Seorang remaja pada masa ini akan berusaha dengan cara apapun agar tetap diterima oleh group atau kelompok teman sebayanya. Salah satu usaha seorang remaja lakukan agar tetap diterima oleh kelompoknya adalah mengikuti ajakan-ajakan temannya untuk mengikuti kegiatan atau trend tertentu yang sedang teman-temannya lakukan atau ikuti.Salah satu trend yang diikuti oleh remaja adalah bermain game online.

Game online adalah game yang berbasis elektronik visual serta menggunakan jaringan internet. Beck (2007) menyebutkan game online adalah game komputer yang dapat dimainkan oleh multipemain melalui internet. Biasanya disediakan sebagai tambahan layanan dari perusahaan penyedia jasa online atau dapat diakses langsung (mengunjungi halaman web yang bersangkutan) atau melalui sistem yang disediakan dari perusahaan yang menyediakan permainan tersebut. Game online memiliki perbedaan yang sangat besar dibandingkan dengan game lainnya, para pemain game online tidak hanya bermain dengan orang yang berada disampingnya namun juga dapat bermain dengan pemainpemain lain yang berada di tempat yang berbeda. Game online sendiri di Indonesia mengalami perkembangan yang luar biasa. Ditunjukkan dari maraknya bermunculan tempat atau warung internet (warnet) yang berprioritas dalam menyediakan jasa penyewaan komputer (PC) untuk bermain game online. Disertai juga tumbuh developer game yang mengakomodasi game-game online yang ada di Indonesia. Seperti yang dapat dilihat dari homepage Asosiasi Game Indonesia (AGI), keanggotaannya sampai sekarang berjumlah hingga dua puluh satu developer. Seperti Lyto, Megaxus, Qeon Interactive, Garuda Games, Toge Productions, dan yang lainnya.

Kesempatan untuk bertemu pemain (gamers) lain merupakan salah satu daya tarik dari game onlinetersebut, sehingga menimbulkan tumbuhnya beragam komunitas-komunitas gamers yang di dalamnya terdapat sekumpulan pemain game onlineyang menjadi satu. Akhirnya game online tersebut menjadi sebuah wadah atau alat jejaring sosial bagi para pemainnya. Game online merupakan sarana hiburan yang bebas dapat dinikmati atau dimainkan oleh berbagai jenis usia baik itu pria maupun wanita, dapat mengakses secara bebas game online tersebut. Ada enam alasan mengapa seseorang bermain game online, yaitu yang pertama untuk meningkatkan mood, mengurangi stres dan depresi, kedua berfungsi memperlambat proses penuaan, yang ketiga untuk mengajarkan kegagalan, yang keempat membantu meningkatkan kemampuan seseorang untuk mengambil keputusan dengan lebih cepat, yang kelima membantu proses pembelajaran, dan terakhir berfungsi meningkatkan kemampuan motorik individu (Permana, 2015).

Di Indonesia sendiri mayoritas yang memainkan game online adalah kalangan remaja hingga dewasa yang rata-rata berumur 12-30 tahun. Hal tersebut diungkapkan oleh Direktur PT Megaxus Infotech Rita Wijaya, Rita menyebutkan mayoritas pemain game online di Indonesia berusia 12-30 tahun akibat pertumbuhan jumlah penduduk yang masih sangat tinggi (Yuli, 2009). Dari hasil study pendahuluan yang peneliti lakukan, di Gianyar daerah domisili peneliti mayoritas yang memainkan game online adalah remaja hingga dewasa. Cenderung remaja SMP keatas yang bermain game, sedangkan anak SD cukup jarang yang peneliti temukan di warnet game online. Sebagian besar dari mereka yang bermain game online karena ajakan dari teman-temannya untuk bermain bersama-sama. Hal tersebut menyebabkan warnet game online menjadi tempat berkumpul atau nongkrong remaja tersebut. Dari beberapa pengakuan remaja yang bermain di warnet game mereka bermain game online bertujuan untuk bersenang-senang atau hiburan untuk menyegarkan kembali dari kepenatan kegiatan belajar di sekolah maupun tempat les. Selain itu mereka bermain game karena agar bisa berkumpul dengan kelompok temantemannya di warnet beramai-ramai. Selain hal tersebut peneliti juga menemukan beberapa dampak negatif dari game online seperti sering membolos sekolah, kebiasaan mengeluarkan kata-kata kasar dan jorok, menginap di warnet, dan akhirnya menimbulkan kecanduan untuk bermain game online..

Secara umum kecanduan sering digunakan dalam lingkup terkait dengan penggunaan zat adiktif (misalnya alkohol, obatobatan). Semakin berkembangnya zaman dan kehidupan manusia istilah kecanduan tidak lagi selamanya melekat pada penggunaan zat adiktif tetapi dapat serta melekat pada suatu hal tertentu yang dapat menimbulkan ketergantuntungan pada seseorang baik secara fisik atau psikologis. Menurut Cooper (Dyah, 2009) berpendapat bahwa kecanduan merupakan perilaku ketergantungan pada suatu hal yang disenangi. Individu secara otomatis akan melakukan apa yang disenangi pada kesempatan yang ada. Kecanduan juga dapat diartikan sebagai suatu kondisi yang menyebabkan individu merasakan ketergantungan terhadap suatu hal yang disenangi pada berbagai kesempatan yang ada akibat kurangnya kontrol terhadap perilaku yang dilakukan individu sehingga merasa terhukum apabila tidak memenuhi hasrat terhadap kesenangan tersebut.Maka dari itu kecanduan game online dapat diartikan sebagai suatu keadaan seseorang yang terikat pada kebiasaan yang kuat dan sulit untuk lepas bermain game online serta ketergantungan untuk bermain terus. 
Salah satu contoh kasus kecanduan game online di Gianyar adalah seorang remaja dikeluarkan oleh tempatnya bekerja karena membolos masuk kerja untuk bisa bermain game online karena kebetulan sedang ada event di game yang dia mainkan (Wiguna, 2017). Selain bolos bekerja ada juga yang membolos sekolah seperti diberitakan oleh Bali Post, dalam sidak warnet di Gianyar, Satpol PP menemukan tiga siswa berseragam sekolah sedang asyik bermain game online di warnet. Dalam sidak warnet di Jalan Yudistira Gianyar, ditemukan siswa SMKN 1 Mas Ubud, Gusti TA dan siswa SMA Dwijendra, I Ketut Ari MK. Keduanya mengaku memang bolos dari sekolah. Menariknya, siswa itu sudah dua kali tertangkap membolos dari sekolah dan sedang bermain di warnet.Selain dua siswa itu, di tempat terpisah, warnet sebelah barat terminal Kebo Iwa juga ditemukan siswa SMAN 1 Blahbatuh, Komang WB yang sedang asik main game online (Dharmada, 2015).

Dari hasil observasi awal pada studi pendahuluan yang dilakukan oleh peneliti beberapa ciri-ciri kecanduan yang ditunjukkan oleh remaja yang bermain game online adalah hampir setiap hari datang untuk bermain game online, dalam sehari menghabiskan waktu lebih dari 8 jam untuk bermain, kurang merawat diri dan tidak teraturnya makan serta minum karena keasyikan bermain game online, menjual barang berharganya seperti handphone dan lain-lain untuk bermain serta membeli voucher game online, sehari atau lebih tidak pulang karena menginap di warnet untuk bermain. Selain itu menurut Yee (2002) ciri-ciri kecanduan pada game online adalah pertama, cemas, frustasi, dan marah ketika tidak dapat melakukan permainan, yang kedua adalah perasaan bersalah ketika bermain, yang ketiga terus bermain meskipun sudah tidak menikmatinya lagi, keempat yaitu teman atau keluarga mulai berpendapat ada sesuatu yang tidak beres dengan individu karena game online, yang kelima timbulnya masalah dalam kehidupan sosial, dan yang terakhir munculnya masalah dalam hal finasial serta hubungan dengan orang lain.

Berlebihannya waktu dalam sehariyang digunakan oleh para remaja yang sudah kecanduan untuk bermain bermain game online mengakibatkan interakasi sosial yang dilakukan remaja tersebut menjadi sangat kurang. Johnson (1988) mengatakan di dalam masyarakat, interaksi sosial adalah suatu hubungan timbal balik antara individu dengan individu lainnya, individu dengan kelompok dan sebaliknya.Interaksi sosial memungkinkan masyarakat berproses sedemikian rupa sehingga membangun suatu pola hubungan. Dari kurangnya interaksi menyebabkan hubungan remaja dengan orang lain menjadi berkurang, contohnya hubungan dengan orangtuanya, pacar, dan teman diluar game online. Hal tersebut dapat menjadi sebuah potensi yang dapat menimbulkan sebuah masalah yang mengganggu remaja tersebut.

Dari hal-hal yang sudah dipaparkan oleh peneliti diatas apakah benar kecanduan game online tersebut bisa menjadi potensi masalah yang menyebabkan remaja untuk mengalami masalah dengan dirinya sendiri, orangtua atau keluarga, pacar, dan temannya.

\section{METODE PENELITIAN}

\section{Desain Penelitian}

Tipe penelitian kualitatif merupakan suatu penelitian yang bermaksud memahami fenomena tentang apa yang dialami oleh subjek penelitian misalnya perilaku, persepsi, motivasi, tindakan dan lain-lain secara holistik dan dengan cara deskripsi dalam bentuk kata-kata dan bahasa pada suatu konteks khusus yang alamiah serta dengan memanfaatkan berbagai metode alamiah (Tohirin, 2012). Gunawan (2013) menjelaskan bahwa penelitian dengan pendekatan kualitatif menekankan analisis proses dari proses berpikir secara induktif yang berkaitan dengan dinamika hubungan antar fenomena yang diamati dan senantiasa menggunkan logika ilmiah. Penelitian kualitatif bertujuan mengembangkan konsep sensitivitas pada masalah yang dihadapi dan mengmbangkan pemahaman akan satu atau lebih dari fenomena yang dihadapi. Penelitian kualitatif merupakan sebuah metode penelitian yang digunakan dalam mengungkapkan permasalahan dalam masyarakat sehingga dapat dijadikan suatu kebijakan untuk dilaksanakan demi kesejahteraan bersama.

Penelitian kualitatif memiliki beberapa pendekatan yang digunakan sesuai dengan masalah yang ingin diteliti. Dalam penelitian ini peneliti menggunakan pendekatan fenomenologi. Fenomenologi adalah penjelasan sebuah fenomena yang terjadi dalam situasi yang alami yang terjadi pada responden setiap hari (Ghony \& Almanshur, 2012). Berdasarkan hal tersebut, peneliti ingin memahami dan mempelajari berdasarkan sudut pandang serta keyakinan langsung dari individu yang bersangkutan, sebagai individu yang mengalami langsung kejadian yang berkesan menurut individu dan berusaha memahami arti peristiwa serta hubungannya terhadap individu tersebut yang berada dalam situasi tertentu. Maka dari itu, pendekatan fenomenologi yang digunakan dalam penelitian ini diharapkan dapat mengetahui pengalaman individu yang mengalami kecanduan bermain game online.

\section{Unit Analisis}

Menurut Moleong (2013) unit analisis atau yang biasa disebut kajian analisis merupakan pengambilan sampel dengan merinci kekhususan yang ada dalam sebuah kasus yang unik, bukan untuk sebuah generalisasi melainkan mengumpulkan sebanyak mungkin informasi.Moleong juga menyebutkan Kajian analisis ini dapat dibedakan menjadi dua, kajian analisis bersifat perseorangan dan kajian analisis bersifat kelompok, sehingga dalam penelitian ini kajian analisis yang digunakan berada pada tingkat kajian kelompok. Pada tingkat analisis kelompok ini, peneliti memusatkan pengumpulan data pada responden-responden yang nanti akan menjadi sebuah kelompok. Tingkat analisis kelompok berarti mengumpulkan apa yang terjadi dalam kegiatannya, apa yang memengaruhinya, dan bagaimana sikap individu yang nanti akan dikelompokkan tanpa melihat siapa individu tersebut (Moleong, 2013). Maka dari itu, pengumpulan data pada penelitian ini, fokus pada pengalaman individu yang sudah terjadi dan respon yang didapatkan individu ketika mengalami masalah dengan game online yang nanti akan dikelompokkan. 


\section{Subjek Penelitian}

Ahmadi (2014) menyebutkan pada penelitian kualitatif, responden penelitian yang digunakan adalah individu yang lebih banyak atau paling banyak terlibat dalam peristiwa dan atau memiliki informasi penting yang diperlukan dalam penelitian. Maka dari itu, pemilihan subjek penelitian harus mewakili sejumlah informasi yang dibutuhkan dalam penelitian. Untuk memperoleh data yang diinginkan saat melakukan penggalian data sangat penting untuk memilih subjek maupun informan penelitian yang sesuai dan tepat. Pemilihan subjek berdasarkan karakter subjek yang diinginkan sesuai dengan tujuan penggalian data. Maka dalam penelitian ini karakter subjek penelitian yang diambil adalah:

1. Jenis kelaminnya tidak dibatasi

2. Berstatus masih sekolah, kuliah, bekerja dan belum bekerja.

3. Sudah bermain game online setidaknya menimal 1 Tahun

4. Masih aktif bermain game online sampai sekarang

5. Sehari mengahabiskan waktu 8 jam hingga lebih untuk bermain

6. Hampir setiap hari datang ke warnet untuk bermain game online

Jumlah subjek yang digunakan dalam penelitian ini tidak ditentukan, karena dalam penelitian kualitatif yang menjadi tolak ukur pengambilan data bukanlah jumlah subjek atau responden melainkan informasi serta data yang berhasil diperoleh dari subjek tersebut. Selain menggali informasi dari subjek yang telah ditentukan, diperlukan informasi tambahan yang berfungsi sebagai penguat data yang telah diperoleh dari subjek. Pada penelitian ini, peneliti menggunakan teknik purposive sampling sebagai teknik sampling karena peneliti menginginkan subjek dalam penelitian ini merupakan individu yang paling banyak terlibat dalam peristiwa dan atau memiliki informasi yang diperlukan dalam penelitian. Purposive sampling merupakan jenis sampling yang diterima untuk situasi-situasi khusus (Ahmadi, 2014). Responden dalam penelitian ini hanya akan menggunakan responden dengan kriteria yang telah ditetapkan yang sesuai dengan tujuan dari penelitian.

Informasi tambahan tentang penelitian ini aka digali dari beberapa informan.Informan ini dipilih berdasarkan random sampling yang dilakukan oleh peneliti dan kemudian diberikan kuisoner untuk memperoleh informasi tambahan yang digunakan sebagai penguat dan pelengkap data penelitian ini.Informan yang dipilih berdasarkan random sampling adalah remaja berusia 17-22 tahun.

\section{Teknik Penggalian Data}

Data dalam kualitatif adalah apa yang dikatakan oleh orangorang yang diajukan seperangkat pertanyaan oleh peneliti (Ahmadi, 2014). Menurut Patton dalam Ahmadi (2014), apa yang orang-orang katakan, merupakan sumber utama data kualitatif, apakah apa yang individu katakan diperoleh secara verbal melalui suatu wawancara atau dalam bentuk tertulis melalui analisis dokumen atau respon survei.
Data yang diperoleh didapat melalui teknik wawancara dan observasi dari pernyataan responden maupun orang lain yang termasuk dalam pengalaman dari responden.

Teknik penggalian data yang digunakan dalam penelitian kualitatif lebih menekankan pada jenis teknik wawancara khususnya wawancara mendalam (Ahmadi, 2014). Patton dalam Ahmadi (2014) juga mengatakan bahwa cara utama yang dilakukan oleh para ahli metodologi kualitatif untuk memahami persepsi, perasaan dan pengetahuan orang-orang adalah wawancara mendalam dan intensif. Maka dari itu, teknik yang digunakan dalam penelitian ini adalah wawancara.

Ahmadi (2014) membagi jenis wawancara kedalam 3 jenis yaitu wawancara terstruktur, wawancara tidak terstruktur dan wawancara terbuka tersandar. Penelitian ini menggunakan teknik wawancara terbuka standar karena pertanyaanpertanyaan wawancara telah ditulis sebelumnya secara pasti dengan cara yang sama dan kemudian ditanyakan selama proses wawancara. Pertimbangan yang cermat perlu diberikan sebelum wawancara tentang bagaimana menyusun kata-kata pada masing-masing pertanyaan. Tujuan utama dari wawancara terbuka standar yaitu untuk meminimalkan pengaruh wawancara dengan menanyakan pertanyaan yang sama kepada masing-masing responden.

\section{Teknik Pengorganisasian dan Analisis Data}

Menurut Moleong dalam Ghony dan Almanshur (2012), tahapan pengorganisasian data dalam kualitatif secara umum dapat dibagi menjadi tiga sebagai berikut:

\section{Tahap pra-lapangan}

Pada tahap ini peneliti menyiapkan secara detail tentang rancangan penelitian agar bisa dijadikan patokan oleh peneliti. Rancangan penelitian ini bisa berupa panduan wawancara dan karakteristik responden yang digunakan dalam penelitian ini. Penjajakan dan penilaian lokasi penelitian sangat penting dilakukan agar peneliti bisa mempersiapkan segalanya dan mengenal medan penelitian dengan baik.

\section{Tahap lapangan}

Pada tahap lapangan, peneliti harus memperhatikan beberapa hal seperti latar penelitian dan persiapan diri yang matang, menjalin hubungan yang baik dengan responden agar responden bisa bekerjasama dengan baik.

\section{Tahap analisis data}

Data yang telah dikumpulkan dalam tahap lapangan tentu saja tidak berbentuk angka seperti dalam penelitian kuantitatif namun lebih berupa narasi, deskripsi, foto, dokumen tertulis maupun tidak tertulis (Poerwandari, 1998). Pengolahan dan analisis data dimulai dengan pengorganisasian data. Data yang telah didapatkan oleh peneliti seperti hasil wawancara harus peneliti organisasikan dengan baik, rapi, sistematis dan selengkap mungkin. Pemberian kode kualitatif merupakan suatu bagian integral dari analisis data dan dipandu dengan pertanyaan-pertanyaan penelitian dan mengarahkan pada pertanyaan-pertanyaan baru.

Strauss dalam Ahmadi (2014) mendefinisikan tiga jenis pengodean data kualitatif, yaitu, pengodean terbuka, pengodean aksial dan pengodean selektif. 
Pada pengkodean terbuka dilaksanakan selama tahap pertama selama pengumpulan data. Peneliti menempatkan tema dan menandai kode atau label awal dalam suatu usaha pertama untuk memampatkan kumpulan data ke dalam kategorikategori (Ahmadi, 2014). Peneliti membaca dengan perlahan catatan lapangan, sumber historis atau data lainnya, mencari istilah kritis, peristiwa-peristiwa penting atau tema-tema yang kemudian dicatat (Ahmadi, 2014). Peneliti terbuka untuk menciptakan tema-tema baru untuk mengubah kode-kode permulaan ini dalam analisis berikutnya.

Pengkodean terbuka membawa tema ke permukaan dari kedalaman didalam data. Tema-tema mempunyai tingkat abstraksi yang rendah dan dari pertanyaan penelitian permulaan dari peneliti, konsep dalam literatur, istilah yang digunakan oleh para anggota di tempat-tempat sosial atau pikiran baru yang distimulasi oleh penyelaman ke dalam data.

Pada pengodean aksial, peneliti memulai dengan sejumlah kode permulaan yang terorganisasi atau konsep permulaan (Ahmadi, 2014).Pada tahap pengodean ini, peneliti memfokuskan pada tema yang dikode awal lebih dari yang ada pada data.Kode tambahan atau ide yang baru bisa muncul selama tahap pengodean ini berlangsung dan peneliti mencatatnya, namun demikian tugas utama peneliti yaitu untuk meninjau kembali dan menguji kode permulaan.

Pada tahap pengodean aksial, peneliti tidak hanya menstimulasi pemikiran tentang hubungan antara konsep atau tema, tetapi juga akan menghasilkan pertanyaan-pertanyaan baru. Tahap pengodean ini juga dapat menggambarkan penurunan beberapa tema atau pengujian yang lainnya secara lebih mendalam (Ahmadi, 2014).

Tahap pengodean yang terakhir yaitu pengodean selektif yang meliputi scanning data dan kode-kode sebelumnya. Peneliti mencari secara selektif kasus-kasus yang menggambarkan tema-tema dan membuat perbandingan serta membedakan setelah sebagian besar pengumpulan data diselesaikan. Selama pengodean selektif, tema-tema utama atau konsep-konsep utama akhirnya mengarahkan pencarian oleh peneliti. Peneliti mengorganisasi kembali tema-tema khusus yang diidentifikasi dalam pengodean sebelumnya dan mengerjakan dengan teliti lebih dari satu tema (Ahmadi, 2014).

\section{Teknik Pemantapan Kredibilitas Penelitian}

Ada tiga kegiatan yang dapat dilakukan oleh peneliti kualitatif untuk meningkatkan temuan yang dapat dipercaya yang akan dihasilkan, yaitu dengan memperpanjang keterlibatan, pengamatan yang cermat dan juga triangulasi. Pada penelitian ini, peneliti menggunakan teknik triangulasi untuk memperbaiki kemungkinan temuan dan interpretasi yang akan dapat dipercaya (Ahmadi, 2014).

Menurut Denzin dalam Ahmadi (2014), terdapat empat model yang berbeda dari triangulasi sebagai berikut:

1. Triangulasi data adalah penggunaan sumber data yang beragam dalam studi,

2. Triangulasi investigator/peneliti adalah penggunaan beberapa peneliti atau elevator yang berbeda,
3. Triangulasi teori adalah penggunaan perspektifperspektif ganda untuk menginterpretasi seperangkat data tunggal,

4. Triangulasi metodologis adalah penggunaan metodemetode ganda untuk menstudi masalah atau program tunggal.

5. Triangulasi interdisiplin adalah menggunakan disiplindisiplin yang lain seperti seni, sosiologi, sejarah, dansa, arsitektur dan antropologi untuk mengiformaskan proses penelitian dan bisa memperluas pemahaman terhadap metode dan substansi.

Pada penelitian ini model triangulasi data yang digunakan adalah model triangulasi data dan triangulasi teori.

\section{HASIL PENELITIAN}

Dari hasil wawancara yang dilakukan ke pada lima responden didapatkan informasi yaitu ke lima responden sudah lama bermain game online. Subjek sudah mulai bermain rata-rata sejak SD - SMP sehingga sampai sekarang sudah lebih dari 7 tahun responden sudah bermain game online. Alasan utama yang menyebabkan ke lima responden bermain game online adalah karena ajakan teman untuk bermain dan kemudian merasa asyik, suka dan akhirnya lanjut bermain game online sampai sekarang.Dari hasil wawancara diperoleh hasil berupa beberapa masalah yang subjek alami akibat kecanduannya bermain game online.

Dari hasil wawancara yang dilakukan ke pada lima responden didapatkan informasi yaitu ke lima responden sudah lama bermain game online. Subjek sudah mulai bermain rata-rata sejak SD - SMP sehingga sampai sekarang sudah lebih dari 7 tahun responden sudah bermain game online. Alasan utama yang menyebabkan ke lima responden bermain game online adalah karena ajakan teman untuk bermain dan kemudian merasa asyik, suka dan akhirnya lanjut bermain game online sampai sekarang. Dari hasil wawancara diperoleh hasil berupa beberapa masalah yang subjek alami akibat kecanduannya bermain game online.

Permasalahan-permasalahan apa saja yang dialami oleh subjek dapat dilihat pada Tabel 1 (terlampir). Pada masalah yang dialami dapat digolongkan menjadi 4 pokok permasalahan secara umum. Kategori pertama yaitu permasalahan individu, terdapat beberapa masalah terkait diri subjek sendiri akibat dari bermain game online yaitu lupa waktu karena keasyikan bermain, masalah keuangan serta pola hidup yang tidak sehat. Pada pokok permasalahan kedua adalah permasalahan keluarga.

Pada permasalahan ini terdapat beberapa masalah juga yang dialami oleh subjek dengan keluarganya akibat bermain game online. Seperti orang tua tidak menyetujui atau suka subjek bermain game online dan dimarahi oleh orangtua dan diperketat pengawasan kepada subjek sehingga subjek tidak leluasa kembali bermain game online. Pokok permasalahan yang ketiga dalah permasalahan yang subjek alami dengan pacarnya akibat bermain game online. Yaitu tidak ada waktu untuk pacar atau intimasi berkurang sehingga menyebabkan berakhirnya hubungan subjek dengan pacarnya tersebut. 
Permasalahan yang terakhir adalah permasalahan yang subjek alami dengan temannya sendiri akibat dari bermain game online. Permasalahan tersebut adalah subjek berkelahi atau bertengkar dengan temannya karena ada ketidakcocokkan di game online atau salah pengertian dangan temannya.

Untuk mengatasi permasalah tersebut subjek menggunakan beberapa coping atau tindakan yang subjek lakukan untuk menyelesaikan masalah yang dialami oleh subjek. Pada permasalahan yang menyangkut individu subjek melakukan beberapa coping untuk mengatasi permasalahan individu tersebut seperti mengatur waktunya bermain game, berusaha mengurangi bermain game, memaksakan berhenti bermain game, menyewakan sepeda motornya untuk mendapatkan uang, meminjam dari teman, menginap dirumah teman, meminta rokoknya serta minta tolong ditraktir atau dibelikan makan oleh teman.

Pada permasalahan dengan orangtua subjek melakukan beberapa solusi yaitu dengan sembunyi-sembunyi pergi untuk bermain game online, berhenti sejenak bermain game online kalau orang tua sudah tidak marah lagi lanjut bermain game online, membuktikan diri walaupun masih aktif bermain game online tapi tetap produktif dan bertanggung jawab dan sudah menghasilkan uang sendiri atau sudah mulai mandiri sehingga orangtua mengurangi mengatur subjek.

Permasalahan dengan pacar, coping yang dilakukan subjek adalah meminta maaf terhadap pacarnya serta meluangkan waktu sejenak untuk kadang-kadang mengajak pacar jalanjalan. Solusi berikutnya jika masalah tersebut menyebabkan subjek putus adalah mencari pacar baru yang bisa mengerti dan menerima kesukaan subjek bermain game online. Dipermasalahan yang terakhir subjek cenderung hanya pasif menunggu temannya tersebut untuk meminta maaf, kalau tidak meminta maaf subjek cuek saja dan mendiamkan hal tersebut.

Dari beberapa coping yang dilakukan oleh subjek ada beberapa yang efektif dan ada juga yang tidak efektif.Peneliti memberikan skala pada coping yang dilakukan subjek berdasarkan dengan tingkat efektivitasnya, dengan skala paling efektif adalah 4 dan tidak efektif adalah 1. Dikatakatan coping subjek tidak efektif jika setelah melakukan coping tersebut muncul masalah susulan yang mengganggu subjek. Coping yang dilakukan oleh subjek dapat dilihat pada Tabel 2 (terlampir).

\section{PEMBAHASAN DAN KESIMPULAN}

\section{Masalah Yang Dialami}

Berdasarkan hasil penelitian yang sudah dipaparkan tabel diatas didapatkan hasil masalah-masalah apa saja yang dialami oleh gamers. Masalah yang dialami oleh gamers bisa dibagi menjadi 4 pokok permasalahan yaitu:

Masalah terkait dengan individu

Adalah masalah yang dialami oleh remaja terkait dengan dirinya sendiri yang diakibatkan karena kecanduan bermain game online.Subjek mengalami beberapa masalah seperti lupa waktu karena keasyikan bermain game online, masalah keuangan karena berhenti bekerja, dan pola hidup yang tidak teratur. Permasalahan-permasalahan tersebut terjadi karena subjek mengalami kecanduan terhadap game online.

Seperti pendapat Cooper (2000) bahwa kecanduan merupakan perilaku ketergantungan pada suatu hal yang disenangi. Individu secara otomatis akan melakukan apa yang disenangi pada kesempatan yang ada. Hal yang disenangi dalam hal ini adalah game online. Hampir setiap hari subjek bermain game online dengan waktu minimal 8 jam untuk bermain. Sepertiga hari hingga bisa lebih digunakan subjek untuk bermain game online sudah menggambarkan subjek yang kecanduan akan game online.

Kecanduan game online subjek juga bisa dilihat dari masalah keuangan yang seorang subjek alami. Akibat dari begadang keasyikan bermain game online subjek membolos bekerja sehingga subjek diberhentikan oleh tempatnya bekerja karena telah membolos berulang kali, dengan kecanduan game online pola hidup subjek pun mulai tidak teratur. Mulai dari makan yang tidak teratur dimana subjek kadang-kadang bisa cuma sekali saja makan dalam sehari.Tidur yang tidak teratur karena keseringan begadang. Minum minuman dengan kafein dan taurin tinggi seperti extra joss, e'nao, torpedo, joss susu yang tidak baik untuk kesehatan. Hal-hal diatas bisa menggambarkan ciri-ciri kecanduan game online seperti yang diungkapkan oleh Yee (2002) yaitu mulai munculnya masalah dalam hal finasial dan ada sesuatu yang tidak beres dengan individu karena game online.

Masalah terkait dengan keluarga

Masalah yang dialami oleh remaja terkait dengan hubungan terhadap keluarganya yang diakibatkan karena kecanduan bermain game online. Subjek mengalami beberapa masalah terkait dengan keluarga subjek yaitu orangtua tidak menyetujui atau suka subjek bermain game online dan subjek dimarahi dan diperketat pengawasannya sehingga tidak leluasa bermain game online. Permasalahan tersebut muncul karena kembali akibat kecanduan subjek terhadap game online.

Seperti yang diungkapkan oleh Dodes (2003) kecanduan game online adalah keadaan dimana individu terikat pada kebiasaan dan sulit untuk lepas bermain game online serta ketergantungan untuk bermain terus. Hal tersebut yang menyebabkan subjek mengalami masalah dengan orangtuanya. Ketergantungan subjek untuk terus bermain game onlinemenyebabkan orangtua subjek tidak suka dan mulai memarahi subjek dan melarangnya untuk bermain game online, namun karena ketergantungan subjek terhadap bermain game online subjek tetap saja bermain walaupun dengan cara sembunyi-sembunyi. Permasalahan diatas mulai teratasi saat subjek mulai beranjak dewasa dan mulai bisa hidup mandiri dan menghasilkan uang sendiri, sehingga orangtua mulai tidak peduli apakah subjek bermain game online atau tidak.

Masalah terkait dengan pacar

Masalah yang dialami oleh remaja dengan pacarnya atau orang yang diajak berintimasi karena disebabkan oleh bermain game online.Johnson (1988) mengatakan bahwa interaksi sosial adalah hubungan timbal balik antara individu dengan individu lainnya.Delapan jam atau lebih waktu subjek digunakan untuk bermain game online maka berkurang lah 
hubungan timbal balik antara subjek dengan pacarnya tersebut.

Hal itu menyebabkan dimana berkurangnya waktu intimasi subjek dengan pacar sehingga timbulnya masalah seperti bertengkar hingga hubungan berakhir dengan pacar. Sokeanto (2009) mengatakan kalau interaksi sosial tidak akan terjadi jika tidak ada kontak sosial dan komunikasi, dengan jarangnya subjek bertemu pacar sehingga menyebabkan pacar subjek mulai merasa tidak diperhatikan oleh subjek karena subjek terlalu mementingkan game online. Subjek juga kurang melakukan komunikasi dengan pacar seperti saat pacar menelpon atau chat subjek cenderung mengabaikannya atau lama merespon karena lagi bermain game online dan merasa terganggu denga chat atau telepon pacar.

Masalah terkait dengan teman

Adalah masalah yang dialami oleh gamers dengan temantemannya baik diluar atau didalam lingkup game online. Permasalahan dengan teman disebabkan oleh salah pengertian subjek dan temannya ketika bermain game online. Ketidakcocokan ketika bermain juga menjadi penyebab permasalahan tersebut. Seperti yang diungkapkan Soekanto (2009) komunikasi adalah individu memberi tafsiran kepada orang lain yang berwujud pembicaraan, gerak-gerak badaniah atau sikap, perasaan-perasaan apa saja yang ingin disampaikan oleh orang tersebut.

Disini subjek menafsirkan pembicaraan dan sikap temannya ketika bermain game online yaitu subjek menganngap dirinya tidak cocok dengan apa yang di bicarakan temannya atau tidak suka sikap temannya yang mengganggap dirinya terlalu jago dan subjek itu noob, sehingga subjek mulai bermasalah dengan temannya tersebut dari berkelahi kata-kata hingga saling mendiamkan saat ketemu maupun ketika bermain.

\section{Coping}

Coping yang digunakan responden berbasis pada Emotion Focused Coping yang merupakan coping berarah pada mengatur respon emosional terhadap situasi yang menekan. Individu dapat mengatur respon emosionalnya dengan pendekatan behavioral dan kognitif. Problem Focused Coping adalah bentuk coping yang diarahkan pada upaya untuk mengurangi tuntutan dalam situasi yang penuh tekanan. Terfokus pada masalah individu yang akan mengatasi stres dengan mempelajari keterampilan yang baru (Sarafino, 2006).

Dapat dilihat dari solusi yang dilakukan oleh responden. Sebagian besar menggunakan problem focuses coping yang bisa dilihat ketika responden melakukan tindakan secara langsung untuk mengatasi masalahnya tersebut. Terlihat responden menyewakan sepeda motornya untuk mengatasi masalah keuangan. Responden juga melakukan assistance seeking dimana responden mencari bantuan terhadap orang lain dalam hal ini teman responden untuk menyelesaikan masalah responden. Misalnya pada masalah keuangan responden meminta bantuan pada temannya dalam bentuk pinjaman utang. Pada emotional focuse coping responden cenderung bersikap denial, responden menolak masalah yang ada dengan menganggap seolah-olah masalah tersebut tidak ada.Atau mengabaikan masalah yang dihadapinya. Seperti tetap saja bermain game dengan senang walaupun banyak masalah yang terjadi gara-gara dia bermain game.

Setelah digeneralisasi masalah yang dialami responden dapat digolongkan menjadi empat pokok permasalahan yaitu:

Masalah dengan diri sendiri

Adalah masalah yang dialami responden terkait dengan dirinya sendiri seperti lupa waktu, masalah keuangan dan pola hidupnya tidak sehat.

Masalah dengan keluarga

Adalah masalah yang responden alami terkait dengan keluarga gara-gara reponden menjadi gamers. Masalah tersebut seperti orangtua tidak menyetujui responden bermain game tetapi responden tetap bermain game.

Masalah dengan pacar

Masalah yang responden alami dengan pacarnya karena responden bermain game online.Masalahnya adalah responden tidak memiliki waktu berintimasi dengan pacarnya karena asyik bermain game. Mengacuhkan pacarnya seperti tidak membalas chat, sms, telpon karena dianggap mengganggu bermain game saja.

Masalah dengan teman

Masalah yang dialami reponden dengan temannya seperti berkelahi dengan teman gara-gara saling ejek atau berkata kasar di game.

Untuk mengatasi masalah-masalah tersebut responden melakukan coping atau sebuah tindakan serta solusi untuk menyelesaikan masalah tersebut.coping yang dilakukan oleh responden ada yang efektif dan ada juga yang tidak efektif karena menimbulkan masalah baru setelah melakukan solusi tersebut. Dari solusi-solusi yang diberikan responden tidak ada yang memperoleh skala 4 atau sangat efektif.

Ada beberapa solusi yang menurut responden efektif seperti berusaha mengurangi game online dengan cara mencari kesibukan lainnya sehingga responden bisa lupa dengan game online tersebut. Kemudian membuktikan diri kalau responden itu tetap bisa produktif walaupun bermain game.Lalu sudah bekerja dan bisa menghasilkan uang sendiri sehingga dianggap sudah lepas tanggung jawab dari orangtua sehingga bisa bebas bermain game online.

\section{DAFTAR PUSTAKA}

Adli, A. (2014). Pengaruh penggunaan game online terhadap perilaku mahasiswa Universitas Islam Riau Pekanbaru. (Skripsi tidak diterbitkan). Fakultas Ilmu Sosial \& Ilmu Politik Universitas Riau, Pekanbaru.

Ahmadi, R. 2014. Metodologi penelitian kualitatif. Yogyakarta: Ar-Ruzz Media

Beck, J. C., Mitcheel W. (2007).Gamer juga bisa sukses. Jakarta: PT Grasindo.

Chaplin, J.P. (2009). kamus lengkap psikologi terjemahan. Jakarta: Rajawali Pers.

Dharmada, A. (2015), Satpol pp ciduk pegawai dan siswa bolos.

Diunduh

darihttp://222.124.220.45/read/bali/2015/01/29/29033 
/satpol-pp-ciduk-pegawai-dan-siswa-bolos.htmldi akses tanggal 1 Juli 2017.

Dodes, L. M. (2003) The hearth of addiction. New York: Harper Collins Publiser Inc.

Dyah.(2009). Hubungan antara kontrol diri dengan kecanduan internet pada siswa sekolah menengah pertama.(Skripsi tidak diterbitkan). Fakultas Psikologi Univertsitas Muhammadiyah, Syurakarta.

Fairchild, H. P. (1962). Dictionary of sociology. New Jersey: Littlefield, Adams \& Co.

Ghony, M.A., \& Almanshur, F. 2012. Metodologi penelitian kualitatif. Jogjakarta: Ar-Ruzz Media.

Gunawan, I. (2013). Metode penelitian kualitatif: teori dan praktik. Jakarta: Bumi Aksara

Harsono, M. (2014).Pengaruh bermain game terhadap perkembangan remaja. Serpong: Surya University.

Himpsi.(2010). Kode etik psikologi Indonesia. Jakarta: Pengurus Pusat Himpunan Psikologi Indonesia

Hurlock, E.B. (1994). Psikologi perkembangan: suatu pendekatan sepanjang rentang kehidupan. Jakarta: Erlangga.

Johnson, D. P. (1988).Teori sosiologi klasik dan modern, terjemahanRobert M.Z Lawang dari buku sociological theory classical foundersand contemporary prespective. Jakarta: Gramedia.

Lindsay, G. (2005). Game type anda game genre.Di unduh dari

http://www.lgrace.com/documents/Game types and genres.pdf di akses pada tanggal 1 Juli 2017.

Maulana, A. (2015). 3 Hari nonstop main game, pria ini tewas di depan PC. Di unduh dari http://tekno.liputan6.com/read/2162968 diakses tanggal 22 April 2017.

Moleong, Lexy J. 2013. Metodologi penelitian kualitatif. Bandung: PT Remaja Rosdakarya.

Permana, R. W. (2015). Alasan mengapa orang suka bermain vidio game. Di unduh darihttps://www.merdeka.com/gaya diakses tanggal 22 April 2017

Poerwandari, E.K. (1998). Pendekatan kualitatif dalam penelitian psikologi. Jakarta: Lembaga Pengembangan Sarana pengukuran dan Pendidikan Psikologi (LPSP3) UI.

Reza, J. I. (2015). Asyik bermain game, pria ini lupa datang kepernikahannya. Di unduh dari http://tekno.liputan6.com/read/2165335 diakses tanggal 22 April 2017.

Santrock, J.W. (2007). Psikologi pendidikan (edisi kedua).Jakarta: Kencana

Sarafino, E.P. (2006). Health psychology: biopsychosocial interactions. USA: John Wiley \& Sons.

Sarwono, S. W. (2001). Psikologi remaja. Jakarta: Raja Grafindo Persada.

Soekanto, S. (2009).Peranan sosiologi, suatu pengantar. Jakarta: Rajawali Pers.

Soleh, ismail. (2012). Kerentanan anak yang terpapar game online untuk menjadi deliquent. (Skripsi tidak diterbitkan). Fakultas Ilmu Sosial \& Ilmu Politik Universitas Indonesia, Jakarta.
Steinberg, L, (1993), Adolescence Third Edition, McGrawHill, Inc., New York

Syahran, R. (2015). Ketergantungan online game dan penanganannya. Jurnal Psikologi Pendidikan \& Konseling, 1(1), 84-92.

Tohirin.(2012). Metode penelitian kualitatif dalam pendidikan dan bimbingan konseling. Jakarta: PT Raja Grafindo Persada.

Veeger. 1990. Realitas sosial: refleksi filsafat sosial atas hubungan individu-masyarakat dalam cakrawala sejarah sosiologi. Jakarta: PT Gramedia Pustaka Utama.

Wallace, P. (1999). The psychology of internet. Cambridge: Cambridge University Press.

Yee, N. (2002). Understanding MMORPG addiction.Di unduh dari

http://www.nickyee.com/hub/addiction/addiction.pdf diakses tanggal 23 September 2016.

Yuli. (2009). Mayoritas pemain game online berusia 12-30 tahun. Di unduh dari.http://surabaya.tribunnews.com/2009/07/25/may oritas-pemain-game-online-berusia-12-30-tahun diakses tgl 4 juli 2017. 


\section{LAMPIRAN}

Tabel 1

Masalah yang dialami oleh remaja yang kecanduan

\begin{tabular}{|c|c|c|}
\hline No & Jenis Masalah & Deskripsi \\
\hline 1 & Individu & Lupa waktu karena keasyikan bermain \\
\hline 2 & Individu & Masalah keuangan karena berhenti bekerja \\
\hline 3 & Individu & Pola Hidup tidak teratur \\
\hline 4 & Keluarga & $\begin{array}{l}\text { Orangtua tidak menyetujui bermain game } \\
\text { online }\end{array}$ \\
\hline 5 & Keluarga & $\begin{array}{l}\text { Dimarahi dan diperketat pengawasan oleh } \\
\text { orangtua }\end{array}$ \\
\hline 6 & Pacar & $\begin{array}{l}\text { Tidak ada waktu untuk pacar / intimasi } \\
\text { berkurang }\end{array}$ \\
\hline 7 & Teman & $\begin{array}{l}\text { Berkelahi / bertengkar dengan teman terkait } \\
\text { game online }\end{array}$ \\
\hline
\end{tabular}


Tabel 2

Coping dan efektivitas

\begin{tabular}{|c|c|c|c|}
\hline No & Solusi & Efektivitas & Masalah Susulan \\
\hline 1 & $\begin{array}{l}\text { Mengatur waktu kapan untuk } \\
\text { bermain kapan untuk } \\
\text { mengeriakan hal yang lain }\end{array}$ & 2 & $\begin{array}{l}\text { Kadang susah mengatur } \\
\text { wakttunva apalag kalau sudah } \\
\text { hampir sehan-han selalu disi } \\
\text { dengan main game }\end{array}$ \\
\hline & $\begin{array}{l}\text { Benusahamengurangi bermain } \\
\text { dengan menyibukkan din } \\
\text { dengan kegiatan yang lain / } \\
\text { mencari kegiatan lain }\end{array}$ & 3 & $\begin{array}{l}\text { Tidak a da masalah susulan yang } \\
\text { muncul }\end{array}$ \\
\hline & $\begin{array}{l}\text { Memaksa atau secara paksa } \\
\text { berhenti bermain game online }\end{array}$ & 2 & $\begin{array}{l}\text { Tidak bisa berhenti secara } \\
\text { langsungkarenakalaug gak dapet } \\
\text { bemain game online sepertinya } \\
\text { ada yang kurang }\end{array}$ \\
\hline 2 & $\begin{array}{l}\text { Subjek menyewakan sepeda } \\
\text { motor miliknya dengan tariff } \\
350.000 \text { per minggu }\end{array}$ & 2 & $\begin{array}{l}\text { Dengan uang } 350.000 \text { seminggu } \\
\text { tidak cukupmememulikebutuhan } \\
\text { untuk makan, rokok danbermain } \\
\text { game sehingga pola hidup tidak } \\
\text { teratur }\end{array}$ \\
\hline & Meminjam uang pada teman & 1 & $\begin{array}{l}\text { Susah mengembalikan uang } \\
\text { teman karena uang yang } \\
\text { diperoleh pas-pasan }\end{array}$ \\
\hline 3 & $\begin{array}{l}\text { Meminta bantuan pada teman } \\
\text { di wamet seperti meminta } \\
\text { dibelikan makanan, meminta } \\
\text { rokok menginap dinumah } \\
\text { teman }\end{array}$ & 2 & $\begin{array}{l}\text { Kadang gak semua teman siap } \\
\text { membantu jadi kembali pola } \\
\text { hidup tidak teratur }\end{array}$ \\
\hline
\end{tabular}

\begin{tabular}{|c|c|c|c|}
\hline No & Solusi & Efelativitas & Masalah Susulan \\
\hline 4 & $\begin{array}{l}\text { Sembunyi-sembunvi untuk } \\
\text { bermain game online }\end{array}$ & 2 & 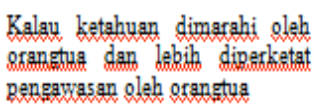 \\
\hline 5 & 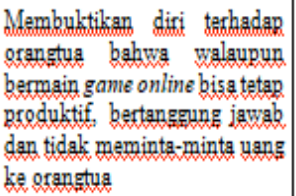 & 3 & $\begin{array}{l}\text { Tidal ada masalah susulan yang } \\
\text { muncul }\end{array}$ \\
\hline 6 & $\begin{array}{l}\text { Sudgh bekeria dan } \\
\text { menghasilkan yang } \\
\text { sehingendiri } \\
\text { mngurangi mengatur kitg. }\end{array}$ & 3 & $\begin{array}{l}\text { Tidal ada masalah susulan yang } \\
\text { muncul }\end{array}$ \\
\hline & $\begin{array}{l}\text { Berhenti seiengl bermian } \\
\text { game online selkitar } 2 \text { sampai } 3 \\
\text { hari kalap sudah tidak marah } \\
\text { lagi bard bermain kembali. }\end{array}$ & 2 & $\begin{array}{l}\text { Siklus massalahnua bembali } \\
\text { berulang lagi }\end{array}$ \\
\hline 7 & $\begin{array}{l}\text { Minta mage dan meluangkan } \\
\text { walktu sejengl dan kadang } \\
\text { kadang mengajak jalan-jalan } \\
\text { pacar }\end{array}$ & 3 & $\begin{array}{l}\text { Tidal ada masalah susulan yang } \\
\text { muncul }\end{array}$ \\
\hline & $\begin{array}{l}\text { Mencari pacar bard yang bisa } \\
\text { mengerti dan menerima } \\
\text { kesulkagn kitg bermain game } \\
\text { online }\end{array}$ & 1 & $\begin{array}{l}\text { Mencari pacar yang seperti itu } \\
\text { cukup susah }\end{array}$ \\
\hline & $\begin{array}{l}\text { Mentungag teman tersebut } \\
\text { meminta magf kalau ensagl wa } \\
\text { sudlah didiamkan saig }\end{array}$ & 1 & $\begin{array}{l}\text { Karena saling gengri untuk minta } \\
\text { magf dulug jadi tidge saling } \\
\text { menvapa stau diam betika } \\
\text { bertemu dengan teman }\end{array}$ \\
\hline & $\begin{array}{l}\text { 1.: sangat tidak } \\
\text { 2.: Tidak efeltif } \\
\text { 3.: efeltif } \\
\text { 4. sangat efeltif }\end{array}$ & & Go to Settin \\
\hline
\end{tabular}

